\title{
Introduction
}

\section{What is narrative research?}

\section{Corinne Squire, Molly Andrews and Maria Tamboukou}

I live in terror of not being misunderstood (Oscar Wilde, 'The Critic as Artist')

In the last three decades, narrative has acquired an increasingly high profile in social research, following a series of 'narrative turns' in other disciplinary fields, like history and literary studies. (Hyvärinen, 2010). It often seems as if all social researchers are doing narrative research in some way. Yet narrative research, although it is popular and engaging, is difficult; how to go about it is much discussed. People working in this field are frequently approached by students and colleagues, in and outside academia, asking questions like, 'Should I request respondents to tell stories or not?'; 'What happens if my respondents don't produce any narratives?'; 'What is a narrative, anyway?'and, most regularly, 'What do I do with the stories now I've got them?' Narrative data can easily seem overwhelming: susceptible to endless interpretation, by turns inconsequential and deeply meaningful.

Unlike many qualitative frameworks, narrative research offers no automatic starting or finishing points. Since the definition of 'narrative' itself is in dispute, as indeed is the need for having one in the first place (Tamboukou, 2008), there are no self-evident categories on which to focus as there are with content-based thematic approaches, or with analyses of specific elements of language. Clear accounts of how to analyse the data, as found for instance in grounded theory and in Interpretive Phenomenological Analysis, are rare. There are few well-defined debates on conflicting approaches within the field and how to balance them, as there are, for example in the highly-contested field of discourse analysis. In addition, unlike other qualitative research perspectives, narrative research offers no overall rules about suitable materials or modes of investigation, or the best level at which to study stories. It does not tell us whether to look for stories in recorded everyday speech, interviews, diaries, photographs, tv programmes, newspaper articles or the patterned activities of people's everyday lives; whether to aim for objectivity or researcher and participant involvement; whether to analyse stories' particularity or generality; or what epistemological or ontological significance to attach to narratives.

Despite these difficulties, many of us who work with narratives want to continue and develop this work. Most often, perhaps, we frame our research in terms of narrative because we believe that by doing so we are able to see different and sometimes contradictory layers of meaning, to bring them into useful dialogue with each other, and to understand more about individual and social change. By focusing on narrative, we are able to investigate not just how stories are structured and the ways in which they work, but also who produces them and by what means; the mechanisms by which they are consumed; how narratives are silenced, contested or accepted and what, if any, effects they have. For many of us, problematic as they are, narratives carry traces of human lives that we want to understand. All these areas of enquiry can help us describe, understand and even explain important aspects of the world. It is our hope that this book will 
contribute to this multilevel, dialogic potential of narrative research. In the rest of this Introduction, we explore further the popularity of narrative research, its diverse histories and its theoretical contradictions, in an effort to describe both its complexity and the possibilities for working productively within that complexity.

\section{Narrative research: popularity and diversity}

Narrative is a popular portmanteau term in contemporary western social research. The crowd of much-used summary and outline texts about narrative research (Bold, 2012; Clandinin and Connelly, 2004; De Fina and Georgakopoulou, 2011; Elliot, 2005; Freeman, 2009; Herman, 2009; Holstein and Gubrium, 1999; Langellier and Peterson, 2004; Mishler, 1986; Ochs and Capps, 2001; Plummer, 2001; Polkinghorne, 1988; Riessman, 1993, 2008; Roberts, 2001; Sarbin, 1986; Wengraf, 2001) exemplifies its popularity. So does the recent burst of empiricallybased texts focused on specific studies, (Andrews, 2007; Emerson and Frosh, 2004; McAdams, 2006; Mishler, 1999; Squire, 2007; Tamboukou, 2010), the rich crop of narratively-themed collections of essays (Andrews et al., 2004; Bamberg et al., 2008; Bamberg and Andrews, 2004; Brockmeier and Carbaugh, 2001; Chamberlayne et al., 2000; Clandinin, 2006; Patterson, 2002; Hyvarinen et al., 2010; Stanley, 2010) and the increasing number of books addressing narrative in specific domains such as human development, education, health, sexualities, psychotherapy and social work (for instance, Charon, 2006; Daiute and Lightfoot, 2004; Greenhalgh and Hurwitz, 1998; Hall, 1997; Hyden and Brockmeier, 2011; Lieblich et al., 2004; Mattingley, 1988; Plummer, 1995; Trahar, 2009; Wells, 2011).

Aside from this current ubiquity within social research, 'narrative' is also a term frequently heard in popular discourse. Often, these popular uses of the term work to connote a particularly acute understanding. Politicians or policymakers suggest they are doing their jobs well because they pay close attention to people's everyday 'narratives', or because they themselves have a joinedup 'narrative' of what they are doing. Journalists claim a good understanding of events by spelling out for their audiences the underlying 'narrative'. Citizens are urged to achieve better comprehension of difficult circumstances by reading or hearing the 'stories' of those affected for example, the World Health Organisation pictures the diversity of disability through 'first hand accounts' from across the world (http://www.who.int/features/2011/disability/en/index.html). Sometimes, though, public 'narratives' are treated with suspicion, as obfuscators of the 'realities' they gloss and hide. In addition, the term 'narrative' is used descriptively in popular discourse, as it is in academic humanities disciplines, to indicate the line of thematic and causal progression in cultural form such as in a film or a novel. Here again, 'narrative' may be a good thing - exciting, compelling, insightful - but it may also be criticized - as over-complex, over-simple, too long, too conventional.Both in popular culture and in social research, then, 'narrative' is strikingly diverse in the way it is understood. In popular culture, it may suggest insight into - or concealment of important biographical patterns or social structures - or, simply, good or less good forms of symbol sequence. In social research, 'narrative' also refers to a diversity - of topics of study, methods of investigation and analysis, and theoretical orientations. It displays different definitions within different fields, and the topics of hot debate around these definitions shift from year to year.

On account of this prolixity, many accounts of narrative research begin by exploring the field's 
different contemporary forms. This Introduction is no exception, but it approaches the task a little differently. It sets out two overlapping fields within which narrative research's diversity appears: those of narrative research's history, and its theory. For, we shall argue, narrative research's incoherence derives partly from its divergent beginnings, and partly from the theoretical fault lines that traverse it.

\section{Where does narrative research come from? Historical contradictions}

The antecedents of contemporary narrative social research are commonly located in two parallel academic moves (Andrews et al., 2004; Rustin, 2000). ${ }^{1}$ The first is the post-war rise of humanist approaches within western sociology and psychology. These approaches posed holistic, personcentred approaches, often including attention to individual case studies, biographies and life histories, against positivist empiricism (Bertaux, 1981; Bruner, 1990; Polkinghorne, 1988; Sarbin, 1986). The second academic antecedent to contemporary narrative social research is Russian structuralist and, later, French poststructuralist (Barthes, 1977; Culler, 2002; Genette, 1979; Todorov, 1990), postmodern (Foucault, 1972; Lyotard, 1984), psychoanalytic (Lacan, 1977) and deconstructionist (Derrida, 1977) approaches to narrative within the humanities. These approaches had effects on social research in the English-speaking world from the late 1970s, initially through the work of Althusser, Lacan and Foucault, film and literary critics and feminist and socialist theorists, as it appeared in translations; and in journals such as Ideology and Consciousness and $m f$, and in books like Changing the Subject (Henrique et al., 1984) and later, in the US, Gergen's (1991) and Sampson's (1993) work. ${ }^{2}$ Such work was often interested in story structure and content. But unlike the humanist narrative move within social research, it was concerned with narrative fluidity and contradiction, with unconscious as well as conscious meanings, and with the power relations within which narratives become possible (Parker, 2003; Tamboukou, this volume). It assumed that multiple, disunified subjectivities were involved in the production and understanding of narratives, rather than singular, agentic storytellers and hearers, and it was preoccupied with the social formations shaping language and subjectivity. In this tradition, the storyteller does not tell the story, so much as she/he is told by it.

Despite the theoretical differences, there are many convergences between these humanist and poststructuralist traditions within current narrative research. Most researchers are affected by both conceptual histories. For example, Wendy Hollway and Tony Jefferson use what they have called 'free association narrative interviewing' (2000) to map individuals' biographical accounts of crime in the community. They also apply psychoanalytic understandings of fractured subjects to these individual biographies, and draw on poststructural formulations of the uncertainties of language. ${ }^{3}$ Similarly, Mark Freeman (2004) traces the life histories of individual artists, but at the same time he positions these life histories within the modern western narratives of art that 'write' these lives, and he also pays attention to the unconscious structures of meaning that traverse life stories. Recent studies influenced by the philosopher Gilles Deleuze (Loots and colleages, this volume; Tamboukou, 2010) work with corpuses of data produced by individual, frequently marginalized subjects - while treating those data as networks of narrative meaning distributed across the material world, not fixed to a single biographical subject.

More generally, humanist and the poststructuralist traditions of narrative research are often brought together by their shared tendency to treat narratives as modes of resistance to existing structures of power. This tendency may involve, for instance, collecting the oral histories of 
working class communities. It may mean investigating the (auto)biographical expression of women's subject positions: how women write within the contexts of their lives; and how other women read their texts within the conditions of their own lived, subjective place within power relations (Hydén, this volume; Stanley, 1992; Tamboukou, 2010). It may stimulate a linguistic study of the storytelling sophistication of African-American adolescents (Labov, 1972). Some narrative researchers use extensive life histories in order to understand how personal lives traverse social change (Andrews, 2007; Chamberlayne et al., 2002). Others deploy narratives to try to change people's relations to their social circumstances. This is the terrain of narrative therapy and other therapies that use storied material, as well as of some community research that enables collective storytelling (Sliep et al., 2004). Still other researchers analyse the conditions and effectiveness of community and 'public' narratives (Gready, this volume; Plummer, 1995, 2001).

Politics thus seems at times to bring the two historical trends in narrative research together (Squire, 2005). Nevertheless, their theoretical assumptions about subjectivity, language, the social and narrative itself remain in contradiction. Current syntheses of the two often involve, for instance, maintenance of a humanist conception of a singular, unified subject, at the same time as the promotion of an idea of narrative as always multiple, socially constructed and constructing, reinterpreted and reinterpretable. These contradictions do not go unnoticed. But many researchers think it more important to do useful and innovative work across the contradictions, rather than trying to resolve conflicting positions that are historically and disciplinarily distinct, as well as logically incommensurable.

\section{Theoretical divisions in narrative research}

The historically-produced theoretical bricolage in narrative research is largely responsible for the current wide variability in how researchers conceptualize what is narrative, how to study it and why it is important - as material, method, or route to understanding psychological or social phenomena, or all of these. The following section of the Introduction sketches some obvious and some less obvious theoretical division in contemporary narrative research.

One of the most well-rehearsed differences is between research focused on the spoken recounting of particular past events that happened to the narrator, the person telling the story classically described in Labov's (Labov and Waletsky, 1967; see also Patterson, this volume) work on event narratives - and experience-centred work (see Squire, this volume), exploring stories that range in length from segments of interviews, to many hours of life histories, and that may be about general or imagined phenomena, things that happened to the narrator or distant matters they've only heard about. This second kind of narrative research encompasses varying media, too: not just speech, but also writing - scraps of letters, laundry lists, extensive multivolume diaries - visual materials - photo albums, video diaries - and narratives inhering in objects and actions - the arrangement of objects on mantelpieces, the everyday activities of shopping, cooking and eating (Seale, 2004). It is worth noting here that the event-centred and experience-centred division is for many narrative researchers a heuristic one and the boundaries between them are porous and overlapping - as becomes apparent in Chapters 1 and 2. In any case, such expansion of narrative data seems to some to give the term 'narrative' a meaning so broad as to rob it of descriptive, let alone explanatory power (Craib, 2004). Yet throughout this second field of work, the life experiences that infuse the data constitute the primary topic, the 
true 'narrative' (Bruner, 1990).

What is shared across both event- and experience-centred narrative research, is that there are assumed to be individual, internal representations of phenomena - events, thoughts and feelings - to which narrative gives external expression. Event-centred work assumes that these internal and individual representations are more or less constant. Experience-centred research stresses that such representations vary drastically over time, and across the circumstances within which one lives, so that a single phenomenon may produce very different stories, even from the same person.

A third form of narrative research, which addresses the co-constructed narratives that develop, for instance in conversations between people or email exchanges, does not fit into either of these two initial fields of event- and experience-oriented narrative research. This third field may operate with the assumption that its more 'social,' co-constructed, stories are expressions of internal cognitive or affective states. However, most often, it views narratives as forms of social code, addressing stories as dialogically constructed (Bakhtin, 1981) and not as expressions of internal states. Researchers in this field are interested, rather, in the social patterns and/or functioning of stories, whether the 'stories' are short, disjointed sequences of conversation or much more extensive, exemplifying broad cultural narratives (Abell et al., 2004; Bamberg, 2006; Georgakopoulou, 2007; Plummer, 2001; Squire, 2007).

Narrative research's divergences over whether stories are symbolizing internal individual states or external social circumstances - in itself, a questionable division - relate to a further dichotomy. Are narratives shaped by the audiences to whom they are delivered, and if so, to what extent? For some narrative researchers, the most interesting features of personal narratives lie in what they tell us about individual thinking or feeling, whether the narratives themselves are about events or experiences (Chamberlayne et al., 2002; Hollway and Jefferson, 2000; Labov, 1997). Other researchers are more concerned with the social production of narratives by their audiences: in how personal stories get built up through the conversational sequences in people's talk (Bamberg, 2006; Georgakopoulou, 2007); or how they are tied up with the performance and negotiation of social identities in a common space of meaning (Phoenix, this volume; Riessman, 1993, 2008; Salmon and Riessman, this volume). ${ }^{4}$ Some narrative researchers are occupied more widely with how narratives follow, are constrained by, or resist, larger social patterns of social and cultural storytelling (Gready, this volume; Malson, 2004; Plummer, 2001). Researchers may even view narratives much more generally, as fields of communication traversed by storylines, that do not need to be broken down between narrators and audiences, narratives and contexts, or narrative language and the other materialities involved with narrative (Loots et al., this volume)Narrative researchers may also be interested in how researchers' own 'stories' vary, depending on the social and historical places from which they 'listen' to their data (Andrews, this volume; Riessman, 2002). These primarily social research interests are seen in some narrative researchers who think of stories themselves as expressions of personal states, as well as in those who treat stories as manifestations of social or cultural patterns, though they are commonest among the latter.

Of course, researchers who are mainly interested in what seems like the simplest kind of stories, event narratives told by individuals, also acknowledge that stories are shaped by their listeners. But for them, these social factors are not the defining or most interesting aspects of personal narratives. Similarly, most biographical and life history researchers accept that social formations shape personal stories. Indeed, they often work with this interaction, tracing the impact of social 
factors on individual stories and 'reading' the significance of social change in those stories. However, some biographical researchers claim an irreducible personal bedrock for personal narratives, based in the fundamentals of human experience, which are often unconscious, and therefore not fully reachable by social analysis. Such researchers are not, generally, too interested in the narrative 'performance' of identities in social contexts, the interpersonal construction or 'co-construction' of narratives at the level of sequences of utterances or across an interview, or the shaping of personal narratives by larger social and cultural narratives or metanarratives.

Thw division between socially- and individually-oriented narrative research relates to yet another theoretical divergence: that between narrative researchers who are interested in the agency of narratives and narrators, and those who are either uninterested, interested in a Butlerian, performative form of agency, or finally, those who argue that agency is not linked to narrative. Researchers who are interested in narratives as individualized accounts of experience tend to be the most convinced of the significance of stories as ways of expressing and building personal identity and agency (Bruner, 1990; see also Squire, this volume). Work that addresses event narratives, or stories co-constructed in talk-in-interaction, tends to be least interested in issues of agency, most aware of the varied and 'troubled' subject positions occupied by narrators (see Georgakopoulou, 2007; Labov, 1997; Phoenix, this volume). Narrative research that is interested in unconscious elements of experience is also sceptical about the possibility of individual 'agency', let alone its operation in and through narrative (Craib, 2004). Whether or not such narrative research - event-focused, interested in co-construction and positioning, or psychoanalytically-inflected - operates with a conception of an agentic subject, it does not tie that concept to an assumption that narrative 'makes sense of ' and enables action within lives. This assumption of a necessary link between narrative and agency is found most strongly in approaches to narrative that focus on personal experience.

However, many researchers who are concerned with the social and cultural place of narrative, are also interested in the social effectsor 'agency' of personal stories. Sometimes they pursue this interest by offering a broadly humanist assertion of individuals' and collectives' potential to make changes, alongside a loosely poststructural account of shifting symbol systems of and their interactive relations with the rest of the material world. Alternatively, the concept of performance is often applied in narrative work, lifted from Goffmanian accounts of social roles, and from Butler's (1993) post-Goffman theory of performativity,in order to retain a potential for change within a theoretical framework that puts agency in question. This is a good example of contemporary narrative research's finessing of theoretical incommensurabilities, in this case by ignoring the different concepts of the subject in play around 'performance' or - at best - hoping to resolve them by what has become known as 'strategic essentialism,' that is, the assumption of agentive subjects where politically expedient. ${ }^{5}$ These kinds of lived-with contradictions in narrative research refer us back to the way in which narrative research's emancipatory aims often bring together historically and theoretically distinct traditions of narrative work. Certainly, some researchers' concern with whether narratives - and their work on them - 'make a difference' may lead them to adopt an optimistic position on narrative agency or effectiveness that seems at odds with their theoretical commitments to, for instance, the socially constructing powers of language, and that can be too simple really to address the involved and politically intractable situations within which personal narratives appear and are studied (see Gready, this volume).

A recent articulation of the divisions within narrative research has taken the form of posing 
'small' against 'big' stories (Bamberg, 2006; Freeman, 2006; Georgakopoulou, 2007). Those on the side of 'small' narratives argue that we need to pay more attention to the micro-linguistic and social structure of the everyday, small narrative phenomena that occur 'naturally' between people. These 'small stories' may concern unfolding, anticipated, imaginary, habitual and indefinite events and states, as well as past, singular 'events'; they may also, for some, involve repeated content or themes spread out across interviews or other data (see Phoenix, this volume). They occur in spoken language, but also in writing - text messages, for example - paralanguage and perhaps even in action. This emphasis on 'small stories' brings together the Labovian commitment to research on 'naturally'-occurring stories, and conversation-analytic as well as some discourse-analytic commitments to studying 'natural' language, and applies them to a wider and more social range of narrative phenomena than has previously been addressed in this way, including interactions of the kind previously investigated mostly by conversation and discourse analysts (Bamberg, 2006; Georgakopoulou, 2007). The emphasis on 'small stories' tends to prioritize socially-oriented over individually-oriented narrative research; it pays attention to the 'social' in its most microsocial versions, as well as in its wider, cultural variants. Against such 'small story' arguments, Freeman (2006), Wengraf (1999) and other biographical and life story researchers defend the experiential richness, reflectiveness and validity of big stories. However, writers on the small story side of the debate do recognize the separate value of big story research, and big story researchers often pay attention to the small aspects of their data. For many, the big/small division may not be too significant. Moreover, Freeman (2006) points out the parallel tendencies in some 'small story' research to claim it is the 'real thing', and in some 'big story' research to claim an immanent validating identity behind its narratives. These claims can return proponents on both sides of the argument to the unproblematically expressivist approach to narrative described earlier in this Introduction.

The 'small' versus 'big' story argument overlaps with another contemporary debate over the tyranny of the transcript. Some narrative researchers - for instance those who work with 'small' narratives, or with visual materials - criticize the hegemony, in the narrative field, of interviewobtained transcripts of people talking, usually one at a time, often reflexively, about their life experiences; and the large, content-based, biographical and social interpretations that narrative researchers derive from such materials. The criticisms thus address both the restricted narrative material privileged by transcripts - mostly speech, rarely paralinguistic material, other media, interpersonal interactions or other social context - and the content-based analysis that is prioritized, and that is hard to legitimate from the bare materials of the transcript without a strong reliance. However, the polarity between transcript-based and other forms of narrative research can be overstated. First, there is now increasing variety in the types of materials gathered and analysed in narrative research, as this book demonstrates (see Bell, Davis, Herman and L-C Hyden, this volume; Ryan, 2004) - and problems of the restricted nature of narrative materials, and of the possible overinterpretation of those materials, turn out to appear across narrative media. Second, approaches that are primarily concerned with narrative structure and context (including 'small story' ones), even if they are less focused on extensive verbal transcriptions, also unavoidably address content. Third, thematic, content-based approaches are, increasingly, explicitly interested in context, and in any case have to address structure and context, at least implicitly, since the meanings in which they deal are embedded in these. As with the similar and long-running debate about levels of discourse analysis, a dialogic approach that advocates an address to content, alongside structure and context, is a conceivable and helpful solution (Wetherell, 1998). 
A further interesting aspect of the alleged conflict between structural, content and context-based approaches is that it draws attention to two other important, though largely implicit, divisions within narrative research. The first of these relates to the status of language in contemporary narrative research. Paradoxically, a cursory or non-existent attention to language often characterizes the narrative social research field. Narrative is always defined first of all as a kind of language. Yet research that focuses on narrative as an expression of individual experience, or as a mirror of social realities, tends to bypass the language of stories in order to focus on their meanings, or the social positionings they produce or reflect. Approaches that focus on event narratives or narratives in conversation, or narratives as performance or expression, tend to be interested either in underlying cognitive structures, or in the social, emotional or affective workings of narrative, 'what narrative does', and narrative's effects. Narrative research across media, while frequently interested in the differences that specific media make to narratives, also tends to refer back to cognitive, embodied or experiential commonalities joining these narrative forms. For many such researchers, narrative language is again therefore secondary. It is the transparent window onto narrative's universal human, possibly even biological, significance in individual and social life, its involvement in all patterns of interaction, ethics and 'living in time' (Salmon, 1985; see also Bruner, 1990; MacIntyre, 1984; Seale, 2004). This narrative transcendentalism is very rarely defended; it is assumed to be a self-evident truth. The 'small story' argument, as well as other work that emphasizes the sociality of narrative and its separateness from agency, tends to undo this certainty about narrative's universality and (often) redemptiveness. But the rapid passing-over of narrative language to get to narrative 'meaning' or 'function' or 'effect' is a broad trend in current narrative research, affecting small and large story study alike. A fetishization of narrative language in social research would not be a happy remedy. However, a slower and more attentive reading of narrative language might be (Derrida, 1985).

Asecond and connected theoretical division related to the place of language in narrative research is that between researchers who assume that their data will contain relatively stable and unified narratives of experience, identity and the social world, at least in a particular time and social context; and those who are less convinced that such narratives can be accessed by them, or even that they exist. The degree to which narrative researchers adopt this = poststructural or postmodern take on narrative, relates strongly to their engagement with language's complexity and non-transparency A postmodern approach is commonly argued to compromise the political engagement which many narrative researchers seek. However, narrative research that engages thoroughly with postmodernism does not necessarily exhibit such compromises. Some narrative researchers operate with an extended version of postmodern or poststructuralist critiques of 'narrative', formulating narrative research as a poststructural enterprise, aware of narratives' social positioning as discourses and of the problematics of subjectivity, representation and power; and of narratives' multiplicities, contradictions, elisions, dialogism and materiality (Burman, 2003; Edley, 2002; Hyvarinen et al., 2010; Parker, 2003, 2004; Squire, 2005; Tamboukou, 2010). Such poststructural takes on narrative are now relatively frequent.

One area of poststructuralist theoretical interest has given rise to an extensive debate within the narrative field. This is psychoanalysis, particularly those forms of it that are inflected by Lacanian and postlacanian concerns with the psyche as a form of language, even a 'narrative', in itself. In these accounts, narratives signify unconscious emotions, as well as conscious cognitions and feelings. Consequently, in these accounts, narratives are rarely seen as simple or, necessarily, valuable. Often, they are viewed as forms of dissembling, - 'telling stories' - or as 
therapeutically papering over psychic complexities

(Craib, 2004; Frosh, 2002), . Sometimes, you won't get the 'whole story'; and all stories will be incomplete, since experience and subjectivity cannot fully make their way into language. Psychoanalytic takes on narrative research try to address aspects of experience or subjectivity such as anxiety, or desire, that may fall outside narrative - that seem difficult or impossible to bring into narrative, or to understand from a straightforward approach to story structure or content (Burman, 2003; Chamberlayne et al., 2002; Frosh, 2002; Hollway and Jefferson, 2000; Sclater, 2003).

Debate between these positions relates to their different theoretical formulations of the unconscious, their differing understandings of how far narratives can register unconscious material, and the varied extent to which psychoanalytically-influenced narrative researchers claim interpretive authority. Some psychoanalytic work on narrative interprets research materials 'as if' they were materials from an analytic session. Other psychoanalytic researchers treat their narrative data as indicators of more generally found individual or social structures of feeling. Outside this psychoanalytically-inflected work, questions about the interpretive authority of even the more cautious psychoanalytically-inflected work are frequent, and are often accompanied by queries about the explanatory value of the 'unconscious' as a concept. Many narrative researchers reject psychoanalytic frameworks on the grounds that detailed analyses of story form and content can generate equally rich and nuanced understandings, without needing to assume the existence of an untestable 'unconscious' entity and set of processes (Wetherell, 2005).

But the problems of what is 'in' narrative that is not straightforwardly said or written, and what cannot even be brought into it, remain. They are crucial for many narrative researchers, working in widely divergent theoretical frameworks. Sometimes, these difficulties are formulated in terms of storytellers' and story audiences' cognitively, emotionally and socially divergent narrative worlds, that may or may not be brought into a workable convergence (Herman, this volume; M. Hydén, this volume; Ricoeur, 1984; Salmon and Riessman, this volume). These problems have also given rise to considerable current interest in how to analyse elements of paralanguage in narrative - tone of voice, pauses, laughter - as well as visual elements such as eye movements, facial expression, body posture and gestures, and more broadly, aspects of emotionality and embodiment within narratives. Theoretically, these elements are difficult to incorporate within existing models of narratives. Moreover, they are hard to define and measure, and, just as much as language structure and content, they vary across social and cultural situations. Lars-Christer Hyden (this volume) is one of the few contemporary researchers working rigorously with these narrative elements. Contemporary interest in them indicates the division between researchers who are prepared to settle for relatively straightforward spoken, written, visual, object or action sequences as their materials, and those who are concerned that this specificity about what constitutes the 'language' of narratives, is inadequate.

Finally the problem of what may lie 'outside' narrative raises another issue which implicitly divides narrative researchers, but which is often understood as uniting them. Narrative is almost always said to be about time - not just succession in time, but change through time (Brockmeier, 1993; Bruner, 1990; Ricoeur, 1984). Time, psychically processed, is thought to make us into subjects through its articulation in narrative. Transformation - meaning, not always, but frequently, improvement - is also assumed to be integral to narrative: in the story itself; in the lives of those telling it; even in researchers' own understandings of it.

Through this emphasis, representations of simple contingencies - events that follow each other 
but that have no necessary relation to each other - are taken out of the narrative category. Representations of causal but not chronological or experiential succession are also seen as theoretical, not 'narrative', in nature. Time and succession as prerequisites of narratives have been challenged by narrative scholars, some of whom have turned their attention rather to analyzing narratives as 'process' and 'force'. (see Gibson 1996, Squire, 2005, Tamboukou 2008). Also, from a psychoanalytic perspective, temporally separate events, and events whose relations are not fully describable, may lie next to each other in the archaeological narrative of the unconscious, without any personally meaningful succession being available to us. And researchers trying to build social or psychological theory certainly see a large difference between their models and theories, and the highly particular, almost 'theoretical' causal sequences that characterize personal narratives.

For researchers who are interested in non-verbal aspects of narrative, such as paralinguistic characteristics, moving and still images and objects, narrative chronology also has temporal and semantic patterns that are difficult to assimilate into the conventional view of narrative 'time'. Even film, which itself tells stories in time, involves image successions whose semantic relationships are more complex than those in a verbally told story. Increasingly, even narrative researchers dealing with fairly 'conventional' personal interview data that represent temporal succession and that themselves unfold in time, are reappraising assumptions about progression and transformation in narrative time. When we revisit data, for instance, it is too simple to say that time has sequentially or experientially 'moved on'. We are different people, and the pasts of the data, and our own present reading situation, are as much 'another country' as are materials gathered in situations unfamiliar to us (Andrews, this volume; Freeman, 2009). Describing these complexities temporally, as the co-presence of past and future in the present, for example, does not necessarily capture their multilayered quality better than a spatialized or historical description, unless we assume autobiographical time's priority for narrative research.

Thus, a focus on chronological or experienced 'time' may close off information about unconscious realities and material causalities, both of which may order stories outside time: about non-verbal narrative sequences; and about other, for instance, spatialized and sociohistorical, ways of understanding succession (Clark, 2003; Frosh, 2002; Harrison, 2004; Hollway and Jefferson, 2000; Mishler, 1999; Riessman, 2002; Tamboukou, 2003). Narrative social research has some catching up to do here with literary and cultural studies and social theory, particularly those developed by feminists, which have long adopted more nuanced approaches towards narrative sequencing. This work recognizes, for instance, the co-presence of futurity and past in the present, the reconstruction of the past by new 'presents', and the projection of the present into future imaginings, in ways that do not give an implicit priority to personally experienced time (Mulvey, 1991; Stanley, 1992; Steedman, 1987).

A number of narrative social researchers are now putting into question the use of 'time' as a narrative-defining trope. Psychoanalytically-influenced narrative researchers have been among those most ready to address alternative temporalities - those of the unconscious as well as of lived realities - in their interpretations. Moreover, in a kind of translation of Freud's idea of nachträglichkeit (deferred action) into social research, narrative researchers more generally are becoming increasingly interested in the complex effects of temporal gaps and reinterpretations on our approaches to narrative data (Andrews, this volume; Riessman, 2002; Salmon and Riessman, this volume). At times, state, social, historical or spatial succession and change, as well as processes and traces of change attaching to objects, are taken as 


\section{alternative or additional forms of narrative, with Michel De Certeau's work a}

strong recent influence. (see Andrews, this volume; Langellier and Peterson, 1992; Patterson, this volume, on Polanyi, 1985; also, Clark, 2003; Tamboukou, 2010 and this volume).

The broadening of the concept of narrative to include sequences whose ordering occurs in dimensions other than those of chronologically, verbally and experientially-ordered time could again seem to some to give narrative research a generality that trivializes it (Craib, 2004). However, narrative remains defined in all this work by sequences with a specific order, temporal or otherwise, which takes it beyond description; and by a particularity that distinguishes it from theory.

This sense of 'narrative' as the ordering of particularities fits well with some rather underacknowledged aspects of the term's meanings. Narrative's Latin etymology lies in knowing, not telling. Without overextending its remit, or treating personal narratives as universal theories, research on narratives as ordered representations can indeed claim to be mapping forms of local knowledge or 'theory'. Narrative research thus converges across its differences, not so much in its political interests, but in the possibility of having microsocial and micropolitical effects through the local knowledges that it produces. These knowledges may be particular, but they can enter into dialogue with each other and produce, as happens across the chapters in this volume, larger and more general, though still situated, narrative knowledges.

Narrative research is a multilevel, interdisciplinary field and any attempt to simplify its complexity would not do justice to the richness of approaches, theoretical understandings and unexpected findings that it has offered. We have thus imagined this book as a compass for navigating the seas of narrative research: a resource that can suggest paths to take, but that also allows for diversions and excursions.

\section{Organization of the book}

The idea for the first edition of this book came from a series of narrative symposia which we began running at our Centre for Narrative Research, based at the University of East London more than ten years ago. In the opening paragraph of this Introduction, we described the kinds of questions that we have often heard from those who wish to use narrative in their research, but are not exactly sure how to go about it. In response to questions like these, through the years we have invited narrative researchers from a wide range of fields (for instance education, politics, health) to spend a day talking about the nuts and bolts of their work. Those who came to talk about their work were asked to address a problem or set of problems which they have encountered, to provide a concrete demonstration of how they analyse their data, and finally, to provide an annotated bibliography for participants. Invariably, the days were long, intense and very rewarding. The original idea of this book was toreplicate the framework of the symposia, specifically the concrete demonstration of how to work with narrative methods. Thus we asked our contributors not to present their research findings, but rather to give readers a sense of how they used narrative methods in their scholarly pursuits. Since the publication of the book five years ago, the 'narrative turn' has continued to grow. Narrative scholars are often invited to participate in pre-conference training workshops, in national methods festivals, and other forums. Many people feel that they have heard about narrative research, and may have read some work by narrative scholars. They are curious to learn more, and to find out if it is a methodology that might work for their particular piece of research. What they really want to learn about is 'how do 
you do it.' Unlike a number of other approaches, however, it' $s$ challenging to convey the nuts and bolts of narrative research, not least because there is not a consensus about this. Moreover, some narrative scholars resist the very notion that there is or can be a clear-cut 'how to' toolkit to guide novices who wish to explore the terrain of the discipline. (Indeed, there is even disagreement on the question if terms like 'methodology' and 'discipline' - and 'data' - can or should be applied to narrative research. Does the use of such language invite expectations which are themselves ill-suited to the orientation? )

Our response to the question 'how do you do narrative research' has always been to invite a number of voices into the room, and that is precisely what we have aimed to do with the current collection. We have asked a wide range of narrative scholars to describe in detail how they go about doing their research.

The book begins by setting out some of the key paradigms within narrative research, moves toexploring the world of narratives which extend beyond the textual (including bodies, the internet, radio, photography and family possessions), and closes with chapters which illustrate how narrative can be used to investigate real social problems, and considers some of the ethical dilemmas which researchers confront in their scholarly pursuits.

In Chapter 1 Wendy Patterson introduces narrative analysis by describing the classic and highly influential Labovian account of the structure or 'syntax' of the personal experience narrative - the story of a single event that happened to the narrator in the past. Patterson uses a short extract from her own work on personal narrative of the experience of trauma as a model for analysis, and through it some limitations of the Labovian approach are highlighted. This leads to a consideration of event-centric versus experiential approaches to narrative analysis, and an exposition of the more interpretive experiential perspective.

Chapter 2, by Corinne Squire, examines two large and interrelated narrative research perspectives. It starts by describing the assumptions underlying the experience-centred approach with which Chapter 1 leaves us, an extremely powerful take on narrative as integral to people's lives and sense of themselves, which addresses the semantics rather than the syntax of narrative. The chapter moves on to sketch out that approach's modes of material collection and analysis. Examining the difficulties associated with this approach's potentially over-strong interpretive claims, over-psychological framework and simplifying assumptions about subjects and time, it explores attempts that have been made to depart from such experience-centred models into context-rich frameworks that pay attention to social discourses and practices, and cultural genres. The chapter enumerates the continuing contradictions and continuing difficulties associated with these moves. The chapter returns to many of the narrative examples used by Patterson, but adds a number from Squire's own research, involving stories that HIV positive South Africans tell about living with the virus.

In Chapter 3 Ann Phoenix analyses smaller-scale, interpersonal aspects of 'context', in particular, the interpersonal relations between interviewer and interviewee within which narratives are produced. The chapter analyses the ways in which narratives are co-constructed within such interpersonal contexts. The aim is to demonstrate the complexities of understanding that can be achieved through different levels of analysis of narrative context. The chapter examines how, in interviews, people both demonstrate awareness of what 'society' thinks of them, and also justify their individual positioning, moving in and out of 'troubled subject 
positions'. Such social and emotional contexts also change over time. To demonstrate this approach, the chapter uses extracts from a study of social identities, drawn from an interview with a white mother of a child of mixed-race parentage. In contexts such as these, narrative analysis provides a means to consider the multilayered ways in which research participants understand their situations.

In Chapter 4, Maria Tamboukou picks up the threads of the relationship between power, discourse and history, and offers a Foucauldian approach for using narratives to re-imagine history, investigating the interrelationships between narrative, subjectivity and power. The chapter is divided into three sub-sections, namely, (a) genealogical problematics, a section discussing the particular problems that Foucault's theories raise in narrative research; (b) questions of method, a section where the 'how' of a Foucauldian approach to narrative analysis is under scrutiny; (c) emerging themes, a section where the author draws on her own research to demonstrate some of the research effects of a Foucauldian approach to narrative analysis. Tamboukou argues that rather than being considered as representing realitiy/ies, narratives should be seen as productive: narratives do things, they constitute realities, shaping the social rather than being determined by it. Indeed narrative research informed by Foucauldian insights is particularly concerned with the processes, procedures and apparatuses, whereby truth, power knowledge and desire are interrelated in the production of narratives and in their effects. But are narrative researchers or practitioners and professionals who draw on narrative methods always aware of the effects of what they do? '... [Narrative researchers] ... know what they do. They frequently know why they do what they do; but what they don't know is what what they do does' (paraphrasing Foucault, cited in Dreyfus and Rabinow, 1982: 187).

In Chapter 5, Gerrit Loots, Kathleen Coppens \& Jasmina Sermijn present the use of a rhizomatic narrative perspective to study the re-integration processes of former child soldiers in their postwar communities in Northern Uganda. The self narratives of former child soldiers and the community narratives about the war and re-building of the post-war society are explored, connected and investigated according to the principles of the rhizome concept of the French philosophers Deleuze and Guattari. The rhizome concept refers to an open and decentralized underground root system, which branches out to all sides, unpredictably and horizontally. The rhizome is used as a methodological metaphor to conceive and study narratives as characterized by the principles of multiple entryways, multiplicity, horizontal connectedness, a-signifying ruptures, and cartography. The rhizomatic perspective considers the narrative construction of selfhood as a multi-voiced process of co-constructing a multitude of fragmented, temporal and context-bounded stories, pathways and new voices. This approach fits the cultural-centred approaches which consider narrative as performance, as narrative-in-context.

The second section of the book, Chapters 6-9, explores a range of narrative scholarship which operates across different media.

In Chapter 6, Lars-Christer Hyden refocuses our attention away from the written and spoken word, and redirects us instead to the many ways in which narratives are embodied. Much narrative research has avoided the physical body, and has instead focused on the way in which the body is represented. As a consequence, the effects of the physically present body, and the diseased body, on the sotry and storytelling activity has been excluded from analysis. Hyden's 
work with dementia patients, in contrast, has at its centre a concern with 'broken bodies and narratives,' focussing on five aspects of embodiment: the present body, the storytelling body, the embodied story, the represented body, and the broken body. Hyden argues that bodies including voice, silence, gaze, touch, scent, gesture, positioning and other movements - are never neutral, and that words and memories are both deeply connected to bodily experiences. Hyden challenges researchers to think more carefully about the bodies of both storytellers and listeners, and the ongoing interaction between them.

With Chapter 7, Susan Bell examines the growing field of visual work within narrative research. The chapter opens by contextualising visual narratives within the field of of visual studies by social scientists. It describes two broad approaches to visual narratives (studying social life with images and studying images). Second, it 'walks through' two examples of visual narrative research. The first of these keeps with the theme of embodiment, and offers an interpretation of photographs made by the well-known British artist Jo Spence after she developed breast cancer in 1982 (studying images). The second example is an interpretation of memory, family and history by two sisters in the contemporary US based on a series of objects collected by their mother's and father's families in the United States from the nineteenth century to the present (studying social life with images). The chapter makes a strong argument for the unique contribution and challenges of incorporating visual narratives into the study of social life.

In Chapter 8, Mark Davis expands the discussion to examine the effect of internet technologies on the creation of new kinds of narratives. The chapter assumes that 'internet technologies' (that is, email, browsing engines, webcam, social and sexual networking sites and so on) are extremely diverse and that how they are combined and used in everyday life cannot be easily categorized. Further, the chapter argues that what such technologies are in social terms is much more than the technologies themselves, to paraphrase Heidegger's famous phrase. The chapter then explores the various ways in which narratives of lived experience can be generated through the internet, including in synchronous and asynchronous online chat-rooms, blogs, and in social and sexual networking platforms. A focus here will be practical and ethical concerns. Next, the chapter turns to narrative inquiry of life with the internet, including the public discourse on the impact of internet technologies on selves and social worlds and experience-oriented narratives of everyday life with internet technologies. The chapter concludes by exploring the implications of the assumption that, in some circumstances, narrative and internet technologies are the conditions of possibility for each other.

In Chapter 9, David Herman invites us to explore different approaches to what he calls 'narrative worldmaking', in other words, how storytellers, using many different kinds of symbol systems (written or spoken language, static or moving images, word-image combinations, etc.), prompt interpreters to engage in the process of co-creating narrative worlds, or "storyworlds"--whether they are the imagined, autonomous worlds of fiction or the worlds about which nonfictional accounts make claims that are subject to falsification. He argues that although narrative provides 
the means for creating, transforming, and aggregating storyworlds across various settings and media, different kinds of narrative practices entail different protocols for worldmaking, with different consequences and effects. In order to illustrate this, Herman builds the chapter around an episode which impinged on his own family's personal history: the broadcast of H.G. Wells' War of the Worlds, in the volatile world of 1938.

The third and final section of the book explores how narratives exist within, transform, and are transformed by their location in the real world. Whereas Section I had focused primarily on methodological debates concerning the structure and analysis of narratives, and Section 2 examined narrative research that extends beyond the purely textual, in this final section our attention turns to the relationship between personal and public narratives, demonstrating that meaning is only ever contextual and is thus forever in flux.

Chapter $10 \mathrm{~s}$ an exchange between Phillida ('Phil') Salmon and Cathy Riessman, two very senior narrative scholars, and reflects Bakhtin's sentiment: 'To live means to participate in dialogue ...' Here, the reader must confront the 'messiness' which characterizes narrative practice, and some of the clarity offered by the previous chapters begins to fall away. The authors were originally asked to co-write a chapter on narrative analysis, but they responded by suggesting that instead, they contribute a written exchange of ideas between them. We accepted this, regarding it as fitting that their writing about dialogic narrative would take the form of a dialogue. Sadly, however, Phil Salmon died before the dialogue could be completed, but we have included it in this collection as we feel that it represents the dynamic and contested nature of narrative enquiry. 'Narratives are, in a fundamental sense, co-constructed' Phil Salmon writes, and Cathy Riessman develops this point further: 'The speaker's intent is always met with the analyst's interpretation, which in turn, is situated in discourses, history, politics and culture. It is never ending, always open to re-interpretation'. The meaning of words is never constant, neither for speakers nor listeners. Narrative research which is based on conversations between people is invariably a process of ongoing negotiation of meaning. People answer the questions which they think we are asking them, and we respond to the answers with which we think they have provided us.

Our understanding of their words is always contingent upon our ability to imagine the worlds they are trying to convey. This capacity to see other than what we know changes in time, appearing both to diminish and to grow: sometimes we can no longer find the feelings and dreams which were once ours, and at other times, having seen more of our own life appears to give us greater access to understanding parts of the lives of others which had once evaded us. And so the meaning we discern in the narratives we collect and help to create is always in the process of transformation, is always a becoming.

In Chapter 11, Molly Andrews explores some of the implications of this for narrative research; in Rosaldo's words 'all interpretations are provisional' (Rosaldo, 1989: 8). There is no 'view from nowhere' (Nagel, 1986), and neither is our positioning constant. Rather, in the course of our lives passions shift; those things which we thought we knew well become strange to us; the objects of our affection grow closer to us, or further away. All of this affects us as people, and as researchers. And when we return to our data, our new and altered selves often see things differently from before. There has been an increasing tendency among narrative researchers to revisit former research projects, and this chapter reports on some of those journeys. Central to 
this discussion is a consideration of what constitutes an 'adequate interpretation'. Does someone have special analytic insights simply because they gathered the original data? What right, if any, do we have to challenge the interpretations which researchers make about their work? Is there ever an end-point to narrative analysis, or is it always, and only, 'provisional'? The chapter considers the ongoing relationship between power, history and biography, and how shifting circumstances both of the individual and of society, cause us to understand ourselves and the world which surrounds us in forever changing ways.

In Chapter 12, Margaretta Hydén takes up the theme of narrating sensitive topics by problematizing the very concept of the sensitive topic itself and showing how it is relationally and culturally defined, as well as embedded in power/knowledge relations. Making a useful distinction between sensitive events and sensitive topics, Hydén focuses on methodological strategies in the process of researching sensitive issues in contested areas. She argues that narrative analysis is particularly well-suited for this task, since it gives informants the possibility to develop their points of view uninterrupted and the researcher the opportunity to analyse their stories as emerging in the interviews, in their entirety. The context of the interview thus becomes a central site for the analysis of the chapter, which draws on Hydén's experiences as a social worker and as an academic, particularly focusing on her work with battered women. In this light Hydén addresses the problem of power relations between the interviewer and the interviewee, showing that imbalances and hierarchies are not always well-defined and/or established, Foucault's model of power becoming the theoretical underpinning of such an approach. She further discusses the issue of victimization of the interviewee's experience and finally points to the risks of the circulation of narratives on sensitive points beyond the control of the narrator and indeed the researcher, a problem that is further developed in the final chapter which follows.

In Chapter 13, Paul Gready reflects on the public life of narratives, considering the effects of narrative research once its results reach the public realm, and how the possibility of such effects must be factored into the research. Gready particularly deals with the methodological problem of whether researchers need to anticipate the public life of narratives, and if so in what contexts, why and how. In particular, the chapter focuses on oral testimony narratives, which are an increasingly common focus of interest and research. Evidence from a range of sources advocacy networks, truth and reconciliation processes, Holocaust testimonial video archives suggests both the arbitrariness of testimonial uptake and circulation in the public sphere, and challenges to testifiers' sense of control and ownership when their testimony takes on an unanticipated public life. The main argument made here is that research on public narratives, without an understanding of the public sphere, of the unsafe spaces surrounding the (sometimes) safe spaces of delivery, can become a violation of trust. With voice comes power; the lack of control over representation in human rights reports, the courtroom, the media or elsewhere, marks a return to powerlessness. In this context, to speak is not a one-off event, but a process, spanning various narrations and interpretations. Using case studies, the chapter outlines the methodological challenges posed by the increasingly public life of personal narratives, suggests ways of addressing these problems methodologically and details how individuals and organizations are reclaiming control and ownership over their own life stories, thus outlining a methodological ethics and politics for contemporary testimonial research.

We have ordered the chapters in this way because for us this sequencing was most compelling, developing as it does from basic models of narrative practice to the less concrete and ethically pregnant questions of what happens to our work after it is released it into the public world. We 
are of course aware that readers may choose to dip in and out of the collection in a different sequence, depending upon their interests and preoccupations, and thus we would also like to suggest a few alternative ways of clustering the chapters.

A number of chapters deal with what is referred to as 'sensitive issues'. Although Gready and Margareta Hydén deal with this topic most explicitly, there are a number of other chapters which also explore some of the difficulties which come with this territory. Sometimes sensitive topics reveal themselves not in what is said, but in what cannot be said, or cannot be expressed coherently.. Phil Salmon's piece opens with an attempted suicide, and immediately conveys the cost of telling stories that are missing their connective tissue. Percy's suicide attempt makes no sense to us because it does not appear to be endowed with meaning by Percy. His story doesn't 'work' because he does not offer his listener an account of his actions which can render them 'socially and culturally comprehensible'. It is perhaps this very aspect of narrative deficiency that has contributed to his attempt to end his life. The unspeakability of some sensitive issues emerges in the chapter by Loots, Coppens and Serjimn, as they examine the narratives of former child soldiers in northern Uganda attempting to reintegrate into their communities, constantly negotiating what can be said to whom about what.

Questions of illness and disease are concerns in a number of chapters. Corinne Squire writes about living with AIDS in South Africa, while Mark Davis explores public discourse of the virus and its impact on, and by, internet technologies. Actual bodies are key focus in Lars-Christer Hyden's chapter, which describes the complex communicative processes which extend beyond the world of language. Susan Bell's discussion of the images of the diseased and dying body demonstrate how much lies beyond what can actually be put into words. And finally, that our own dear friend and colleague Phil Salmon did not live long enough to complete her own contribution reminds us that not only the meaning of our words change over time, but so too do our bodies.

Ann Phoenix, in her chapter on 'mixed-race' children, discusses how individuals establish 'an entitlement to talk about racism'. Clare, who is white, describes herself as one who has experienced racism, and indeed feels that in some situations she has experienced more 'prejudice' than her black husband. Key to this discussion are issues relating to what is considered 'sensitive', who can claim to have insight into this, and how issues of power and positionality enter into the interview situation. In Squire's chapter on South African HIV stories we see how individuals meet the challenge to narrate experiences which are both everyday and life-threatening.

Issues of power and narratability run throughout many of the chapters. Building on the work of French philosophers Deleuze and Guattari, Loots, Coppens and Serjimn use the rhizomatic metaphor as a tool for exposing the 'underground root system' of narratives. Maria Tamboukou adopts a Foucauldian analysis to her work with autobiographical narratives of women artists, highlighting the potential of genealogical work to uncover "new questions to interrogating truths of our world'. One of the benefits of adopting such a lens is that it recognizes the forever changing circumstances of our lives, and of our world. This theme is demonstrated in the exchange between Phil Salmon and Cathy Riessman, both in terms of the issues which they raise, and also in Phil Salmon's unforeseen death, which renders the communication with a different layer of meaning than it would have otherwise contained. Molly Andrews also explores the theme of the changing questions that guide our research, and the dynamic nature not only of our interpretations, but of our data themselves. 
The collection of essays also includes a number of 'family stories' either of the researchers themselves. In the opening paragraphs of David Herman's chapter, we are sitting in the home of his grandparents, along with his young father, as they listen to the original broadcast of H. G. Wells' War of the Worlds. Susan Bell invites her readers to join herself and her sister as they endeavor to make sense of objects which had been collected by their parents. Molly Andrews describes the impact that becoming a mother had on her interpretive lens she subsequently brought to her analytic framework, in her attempt to understand the life world of others.

Wendy Patterson's opening chapter of the book helps us to think carefully about what constitutes a narrative, and she demonstrates what can be lost if one focuses exclusively on a linear model of narrative structure. The story of Percy, referred to above, demonstrates the importance we attach to apparent coherence and meaning of narratives. His tale doesn't work because it is not offered in a cultural framework which is recognizable, and hence he is abandoned by others, and even by us, his potential audience. Context cannot be stripped away, nor can it be separated from questions of meaning. Squire's chapter draws our attention to the need for sensitivity towards cultural genres, and Gready's chapter points to the importance of context, not only in terms of understanding the narrative, but also in terms of the interpretive community. When we are conducting our research, what is the context in which it will be read, and how should this feed into decisions about what to write, and what to leave out?

The question of how we hear, and often fail to hear, aspects of the narratives we encounter, and how we decipher their meaning, is an issue which is addressed from a number of different angles throughout the book. We as narrative researchers are crucially a part of the data we collect; our presence, our very bodies, are imprinted upon all that we do. It is left to us then to determine how we account for ourselves in the work that we do, to consider the impact of our own positioning and that of others - that is, those whose lives lie at the centre of our research - on our scholarship. All of the contributors to this volume stand somewhere in relation to the topics which we are exploring, and reflexivity upon this positioning is a part of each of the chapters.

There are yet many other pathways through these chapters; we have attempted to outline but a few. It is our hope that the chapters in this book will provide the readers with much food for thought, and that in the tradition of good narrative research, that they will raise at least as many questions as they answer.

\section{Notes}

1. For a take on the interactions of these traditions through some specific texts, see Hyvärinen (2006).

2. We are not considering here the much larger field of journals and books with these concerns within the humanities and philosophy at this time, that were 'cross-read' by social researchers - journals such as Radical Philosophy, Screen and Signs and books by Coward, Heath, Jameson, Eagleton, Rose, as well as by a range of other French, UK, US and (to some extent) Australian theorists.

3. This form of argument is apparent in for instance Hollway's earlier work in Changing the Subject (Henriques et al., 1984).

4. Ricoeur's (1984) work has had perhaps the greatest effect in promoting this understanding of narrative. 
5. Spivak (1993) has objected to the overuse of 'strategic essentialism' in situations of theoretical and political difficulty. 


\section{References}

Abell, J., Stokoe, E. and Billig, M. (2004) Narrative and the discursive (re)construction of events. In M. Andrews, S. D. Sclater, C. Squire and A. Treacher (eds) Uses of Narrative. New Jersey: Transition.

Andrews, M. (2007) Shaping History. Cambridge: Cambridge University Press.

Andrews, M., Day Sclater, S., Rustin, M., Squire, C. and Treacher, A. (2004) Introduction. In M. Andrews, S. Day Sclater, C. Squire and A. Treacher (eds) Uses of Narrative. New Brunswick, NJ: Transition.

Bakhtin, M. (1981) The Dialogic Imagination ed. by M. Holquist, Austin:University of Texas Press.

Bamberg, M, De Fina, A. and Schiffrin, D. (2008) Selves and identities in narrative and discourse. Amsterdam: John Benjamins

Bamberg, M. (2006) Stories: Big or small. Why do we care? Narrative Inquiry 16(1): 139-47.

Bamberg, M. and Andrews, M. (2004) Considering Counter-Narratives. Amsterdam: John Benjamins.

Barthes, R. (1977) Image Music Text. New York: Hill and Wang.

Bertaux, D. (1981) Biography and Society. Beverly Hills, CA: Sage Publications.

Bold, C. (2012) Using narrative in research. London: Sage

Brockmeier, J. (1993) Translating temporality? Collegium Budapest Discussion Paper Series No. 4, December. http://www.colbud.hu/main_old/PubArchive/DP/DP04-Brockmeier.pdf. [Accessed 16 December 2007].

Brockmeier, J. and Carbaugh, D. (2001) Narrative and Identity: Studies in Autobiography, Self and Culture. Amsterdam: John Benjamins.

Bruner, J. (1990) Acts of Meaning. Cambridge, MA: Harvard University Press.

Burman, E. (2003) Narratives of 'experience' and pedagogical practices. Narrative Inquiry 13(2): 269-86.

Butler, J. (1993) Bodies That Matter. London: Routledge.

Chamberlayne, P., Bornat, J. and Wengraf, T. (eds) (2000) The Turn to Biographical Methods in Social Science. London: Routledge.

Chamberlayne, P., Rustin, M. and Wengraf, T. (eds) (2002) Biography and Social Exclusion in Europe: Experiences and Life Journey. Bristol: Policy Press.

Charon, R. (2006) Narrative medicine: honoring the stories of illness. New York: Oxford University Press.

Clandinin, D. (2006) Handbook of Narrative Inquiry. Newbery, CA: Sage.

Clandinin, D. and Connelly, F. (2004) Narrative Inquiry: Experience and Story in Qualitative Research. New York: Jossey-Bass.

Clark, J. (2003) Urban culture: Representation and experiences in/of urban space and culture. Agenda 57: 3-10.

Craib, I. (2004) Narratives as bad faith. In M. Andrews, S. D. Sclater, C. Squire and A. Treacher (eds) Uses of Narrative. New Jersey: Transition.

Culler, J. (2002) The Pursuit of Signs. Ithaca, NY: Cornell University Press.

Daiute, C. and Lightfoot, C. (2004) Narrative Analysis: Studying the Development of Individuals in Society. Oxford: Oxford University Press.

De Fina, A. and Georgakopoulou, A. (2011) Analysing narrative. Amsterdam: John Benjamins

Derrida, J. (1977) Of Grammatology. Baltimore: Johns Hopkins University Press.

Derrida, J. (1985) The Ear of the Other. New York: Schocken Books. 
Dreyfus, R. and Rabinow, P. (1982) Michel Foucault: Beyond Structuralism and Hermeneutics. Chicago: Chicago University Press Edley, N. (2002) The loner, the walk and the beast within: Narrative fragments in the construction of masculinity. In W. Patterson (ed.) Strategic Narrative: New Perspectives on the Power of Stories. Oxford: Lexington.

Elliot, J. (2005) Using Narrative in Social Research: Qualitative and Quantitative Approaches. London: Sage.

Emerson, P. and Frosh, S. (2004) Critical Narrative Analysis in Psychology. London: Palgrave. Foucault, M. (1972) The Archaeology of Knowledge. London: Routledge.

Freeman, M. (2009) Hindsight: the promises and perils of looking backward. New York: Oxford University Press.

Freeman, M. (2004) When the story's over: Narrative foreclosure and the possibility of renewal. In M. Andrews, S. D. Sclater, C. Squire and A. Treacher (eds) Uses of Narrative. New Jersey: Transition.

Freeman, M. (2006) Life on 'holiday'? In defense of big stories. Narrative Inquiry 16(1): 131-8.

Frosh, S. (2002) After Words. London: Palgrave.

Genette, G. (1979) Narrative Discourse: An Essay in Method. Ithaca, NY: Cornell University Press.

Georgakopolou, A. (2007) Small Stories, Interaction and Identities. Amsterdam: John Benjamins.

Gergen, K. (1991) The Saturated Self. New York: Basic Books.

Greenhalgh, T. and Hurwitz, B. (1998) Narrative Based Medicine. London: BMJ Books.

Hall, C. (1997) Social Work as Narrative: Storytelling and Persuasion in Professional Texts. Aldershot: Ashgate.

Harrison, B. (2004) Photographic visions and narrative inquiry. In M. Bamberg and M. Andrews (eds) Considering Counter-Narratives. Amsterdam: John Benjamins.

Henriques, J., Hollway, W., Urwin, C., Venn, C. and Walkerdine, V. (1984) Changing the Subject. London: Methuen.

Herman, D (2009) Basic elements of narrative. Oxford: Wiley-Blackwell

Hollway, W. and Jefferson, T. (2000) Doing Qualitative Research Differently: Free Association, Narrative and the Interview Method. London: Sage.

Holstein, J. and Gubrium, J. (1999) The Self We Live by: Narrative Identity in a Postmodern World. New York: Oxford University Press.

Hyden, L-C. and Brockmeier, J. (2011) Health, illness and culture. London: Routledge.

Hyvärinen, M. (2006) Towards a conceptual history of narrative. In M. Hyvärinen, A. Korhonen and J. Mykkanen (eds) The Travelling concept of Narrative. Helsinki: Collegium.

Hyvarinen, M., Hyden, L-C., Saarenheimo, M. and Tamboukou, M. (2010) Beyond narrative coherence. Amsterdam: John Benjamins.

Labov, W. (1972) Language in the Inner City: Studies in the Black English Vernacular. Oxford: Basil Blackwell.

Labov, W. (1997) Some further steps in narrative analysis. Journal of Narrative and Life History 7(1-4): 395-415.

Labov, W. and Waletsky, J. (1967) Narrative analysis: Oral versions of personal experience. In J. Helms (ed.) Essays in the Verbal and Visual Arts. Seattle: University of Washington.

Lacan, J. (1977) Ecrits. New York: Norton.

Langellier, K. and Peterson, E. (1992) Spinstorying: An analysis of women'storytelling. In E. C. Fine and J. H. Speer (eds) Performance, Culture and Identity, Westport, CT: Praeger. 
Langellier, K. and Peterson, E. (2004) Storytelling in Everyday Life. Philadelphia, PA: Temple University Press.

Lieblich, A., McAdams, D. and Josselson, R. (2004) Healing plots: the narrative basis of psychotherapy. Washington, DC: American Psychological Association.

Lyotard, J.-F. (1984) The Postmodern Condition. Manchester: Manchester University Press.

McAdams, D.P. (2006) The Redemptive Self: Stories Americans Live By. Oxford University Press.

MacIntyre, A. (1984) Fictional(ising) identity ontological assumptions and methodological productions of 'anorexic' subjectivities. After Virtue. Bloomington, IN: University of Notre Dame Press.

Malson, H. (2004) In M.Andrews, S.D.Sclater, C.Squire and A.Treacher (eds) Uses of Narrative. New Brunswick, NJ: Transaction.

Mattingley, C. (1998) Healing Dramas and Clinical Plots. Cambridge: Cambridge University Press.

Mishler, E. (1986) Research Interviewing: Context and Narrative. Cambridge, MA: Harvard University Press.

Mishler, E. (1999) Storylines: Craftartists' Narratives of Identity. Cambridge, MA: Harvard University Press.

Mulvey, L. (1991) A Phantasmagoria of the female body: the work of Cindy Sherman. New Left Review 188: 136-50.

Nagel, T. (1986) The View from Nowhere. Oxford: Oxford University Press.

Ochs, Elinor and Capps, Lisa (2001) Living Narrative: Creating Lives in Everyday Storytelling. Cambridge, MA: Harvard University Press.

Parker, I. (2003) Psychoanalytic narratives: Writing the self into contemporary cultural phenomena. Narrative Inquiry 13(2): 301-15.

Parker, I. (2004) Qualitative Psychology. Milton Keynes: Open University Press.

Patterson,W. (ed.) (2002) Strategic Narrative: New Perspectives on the Power of Stories. Oxford: Lexington.

Plummer, K. (1995) Telling Sexual Stories. London: Routledge.

Plummer, K. (2001) Documents of Life 2. London: Sage.

Polanyi, L. (1985) Conversational storytelling. In T.A. van Dijk (ed.), Discourse and Dialogue, volume 3 of Handbook of Discourse Analysis 4. London: Academic Press.

Polkinghorne, Donald E. (1988) Narrative Knowing and the Human Sciences. Albany, NY: State University of New York Press.

Ricoeur, P. (1984) Time and Narrative. Chicago: University of Chicago Press.

Riessman, C. (1993) Narrative Analysis. Qualitative Research Methods Vol 30. Newbury Park, CA: Sage.

Riessman, C. (2002) Analysis of personal narratives. In J.Gubrium and J.Holstein (eds) Handbook of Interview Research. Thousand Oaks, CA: Sage.

Riessman, C. (2008) Narrative Methods in the Human Sciences. New York, Sage.

Roberts, B. (2001) Biographical Research. Milton Keynes: Open University Press.

Rosaldo, R. (1989) Culture and Truth: The Remaking of Social Analysis. London: Routledge.

Rosenwald, G. and Ochberg, R. (1992) Storied Lives. The Cultural Politics of SelfUnderstanding. New Haven: Yale University Press.

Rustin, M. (2000) Reflections on the biographical turn in the social sciences. In P. 
Chamberlayne, J. Bornat and T. Wengraf (eds) The Turn to Biographical Methods in Social Science. London: Routledge.

Ryan, M-L. (2004) Narrative across media: the languages of storytelling. Lincoln, NB: University of Nebraska Press.

Salmon, P. (1985) Living in Time: A New Look at Personal Development. London: Dent.

Sampson, E. (1993) Celebrating the Other. New York: Oxford University Press.

Sarbin, T. (1986) Narrative Psychology. The Storied Nature of Human Conduct. New York: Praeger.

Sclater, Day S. (2003) What is the subject? Narrative Inquiry, 13( 2): 317-30.

Seale, C. (2004) Resurrective practice and narrative. In M. Andrews, S. D. Sclater, C. Squire and A. Treacher (eds) Doing Narrative Research. New Brunswick, NJ: Transaction.

Sliep, Y., Weingarten, K. and Gilbert, A. (2004) Narrative Theatre as an interactive community approach to mobilizing collective action in Northern Uganda. Families, Systems and Health, 22(3): 306-20.

Spivak, G. (1993) Interview with Sara Danius and Stefan Jonsson. Boundary 2(20): 24-50.

Squire, C. (2005) Reading narratives. Group Analysis 38(1): 91-107.

Squire, C. (2007) HIV in South Africa: Talking about the Big Thing. London: Routledge.

Stanley, L. (1992) The Auto/Biographical I: Theory and Practice of Feminist Auto/Biography. Manchester University Press.

Steedman, C. (1987) Landscape for a Good Woman. New Brunswick, NJ: Rutgers University Press.

Tamboukou, M. (2010) In the fold between power and desire: women artists' narratives. Cambridge: Cambridge Scholars' Publishing

Todorov, T. (1990) Genres in Discourse. Cambridge: Cambridge University Press.

Trahar, S. (2009) Narrative research on learning. London: Symposium

Wells, K. (2011) Narrative inquiry. New York: Oxford University Press.

Wengraf, T. (2001) Qualitative research interviewing. London: Sage.

Wetherell, M. (1998) Positioning and interpretative repertoires: Conversation analysis and poststructuralism in dialogue. Discourse \& Society 9: 387-412.

Wetherell, M. (2005) Unconscious conflict or everyday accountability? British Journal of Social Psychology 44(2): 169-73. 